doi: $10.15503 /$ jecs20182.195.200

\title{
ARCHITECTURAL DESIGN CONTEST WITH SOCIAL PARTICIPATION AS A PART OF BUILDING CULTURE IN EUROPE
}

\author{
MACIEJ KOWALCZYK \\ Faculty of Architecture, Warsaw University of Technology \\ ul. Koszykowa 55, 00-659 Warsaw, Poland \\ Email address: mckowalczyk@gmail.com
}

\begin{abstract}
Thesis. The culture of organising architectural competitions has a long tradition in Europe. The architectural design contest is used as a democratic tool for selecting the best design solution. In today's European building culture there is a constantly growing need for the social input into the design process. In effect, architectural competitions are facing changes. On the one hand, an architectural design contest needs to fulfill the EU's legal frames. On the other hand, the traditional forms of competions are questioned by society that is searching for a more transprent selection process.

Methods. The study shows the concept of the building culture (Baukultur) as an ideological background of all the building activity in Europe. It describes the role of an architectural competition as an instrument for the high quality development. The author shows current legal frameworks for the design contests included in the EU directives and presents different competition practices in Europe with a focus on Poland.

Results. There are not many examples of architectural competitions that anticipate the social input. It is an effect of not adjusted procurement law. Nevertheless, some exceptions have already been made.

Conclusions. The main difficulty in architectural design contest with social participation is the need of maintaining the legal framework based on the anonymity of the participant. The social input in the case hampers the preservation of this condition, hence various attempts to modify the existing, traditional formulas.

Key words: architecture, building culture, bakultur, architectural design contest, architectural competition, social participation, public procurement
\end{abstract}

\section{INTRODUCTION}

The concept of building culture (Baukultur) originates from the Germanspeaking part of Europe. In contrast to the art of building (Baukunst), which deals with the craft and architecture, the first concept is broader, has an interdisciplinary character and covers the entire built environment as well as related processes.

„Baukultur encompasses existing buildings, including monuments and other elements of cultural heritage, as well as the design and construction of 
contemporary buildings, infrastructure, public spaces and landscapes. ... A high-quality Baukultur is therefore expressed in the application of conscious, well-debated design to every building and landscaping activity, prioritising cultural values over short-term economic gain. High-quality Baukultur thus not only fulfils functional, technical and economic requirements, but also satisfies people's social and psychological needs" (Davos Declaration, 2018). Therefore, politicians, local authorities, private investors and professionals from various fields should be indicated as key figures influencing the culture of building. "One key example of an instrument for fostering high quality is interdisciplinary and widely-debated design competitions" (Davos Declaration, 2018). The Davos document (2018) also emphasizes that, "to be successful, high-quality Baukultur also requires the participation of civil society and an informed and sensitised public." A similar position is expressed in the memorandum of the Architects' Council of Europe (2017).

Why is social participation becoming so important in the process of changes taking place in our cities? Every change raises fear. What is more a process that is not transparent creates a lack of trust. Including local community in the change process from the very beginning makes the society an active participant. In this way, a sense of transparency, responsibility and, as a result, acceptance for changes takes place. Therefore, more often society is involved in the processes like i.e. creation of urban startegies, transformation of public spaces or construction of new buildings.

\section{ARCHITECTURAL DESIGN CONTESTS}

Architectural design contests have a long tradition. However, it is not known when exactly the first architectural competition was organized in Europe. Literature lists here "the famous competition for the solving of Florence's Dome in the mid $15^{\text {th }}$ Century, brillantly won by Filippo Brunelleschi" (Chupin, Cucuzzella, \& Helal, 2015). Werner Szambien (1986), in turn, cataloged 25 architectural competitions that were organized only in the spring of 1794 during the era of the French Revolution, when the emergence of new buildings became the subject of public discussion. It is certain, however, that in the nineteenth century the tool of architectural competition was already consciously used, however, mainly by private investors. In the twentieth century, it became a widely used instrument that ensured the quality of the obtained results. Nevertheless, it must be admitted that many contests in history have generated controversy and disputes.

In Poland, the first regulations of architectural competitions were created thanks to architectural circles that arose at the turn of the 19th and 20th centuries in Lviv, Krakow and Warsaw. The first regulations were formulated in the Polish territory by architects Józef Dziekoński and Czesław Domaniwewski in 1899. It served to organize ten competitions, the first of which, announced in June 1899, concerned the sketch of a residential house at Chmielna and Zielona 
streets in Warsaw (Warsaw Branch SARP, 2001). Due to the subject of the article, it is interesting that at the time, during the Technicians' Association meeting, it was discussed whether it was appropriate to issue public works before the competition jury issued an appropriate ruling. The discussion decided that similar proceedings should not take place due to the freedom of judges' work (Oddział Warszawski SARP, 2001). It can be seen then that the problem of public participation in the architectural competition was already a subject of debate at that time.

The joint codification regarding competition regulations in Poland took place due to the Association of Polish Architects established in 1934, which has since become the main organizer of architectural competitions in Poland. In the years 1945-2000, the SARP organized about 900 contests.

\section{LEGAL FRAMEWORK}

Local authorities, commercial developers preparing a new investment often face the choice of how to choose the best architectural design, and thus what kind of architect they will cooperate with throughout the investment period. While in the case of private investors, the selection procedure is unlimited, public investors are binded by public procurement law, which defines the formal framework for selecting individual entities performing architectural services. It should be emphasized that it is this last group of investors that has the important impact on such processes in our cities as revitalization or the creation of new public facilities of a non-commercial character. As aware of the benefits of the broad public participation in the process, they are wondering how to realise it in the current legal framework.

Currently, within the European Union, these issues are regulated by the Directive 2014/25/EU (2014), which forms the basis for the procedures in individual EU countrites. According to the definitions indicated in the document "'design contests' means those procedures which enable the contracting entity to acquire, mainly in the fields of town and country planning, architecture, engineering or data processing, a plan or design selected by a jury after being put out to competition with or without the award of prizes (Directive 2014/25/ $\mathrm{EU}, 2014)$. Article 98 in its points describes the decisions of the Jury:

"4. Anonymity shall be observed until the jury has reached its opinion or decision.

5. Candidates may be invited, if need be, to answer questions that the jury has recorded in the minutes to clarify any aspects of the projects."

This example shows a discrepancy of approach of the legislator. On the one hand, a traditional competition is anonymous. On the other hand, the more information is collected by a jury, the more suitable project is selected. It shows a formal problem for an investor that wants to involve society in the process how to ensure required anonymity and at the same time to present the project to interested social groups before the competition is settled? 
The Polish Public Procurement Law has a separate chapter dedicated to competitions. In terms of content, it reflects EU regulations (Polish Public Procurement Act, 2017).

\section{CASE STUDIES}

An interesting example is the German competition for the cultural center in Wolfsburg (Stadt Wolfsburg, 2013). In this contest a two-stage formula was used. In this type of competition, in the 1st stage competitors submit only an initial design. After that several works are selected by jury and qualify for the 2nd stage to submit a detailed project. Between the 1st and 2nd stage, comments on the work are formulated. The uniqueness of this procedure consists in the fact that between the stages of the competition an open exhibition was organized in which local residents could participate. In order to comply with the rules of anonymity, photos could not be taken during the exhibition. It was only necessary to fill in the form describing: 'I like the project X because...', 'I do not like the project $X$ because...'. To make the projects understandable for visitors, a guidance was ensured. Then, the judges were acquainted with the questionnaire and on this basis created comments between the stages of the competition. In the seconod stage designs were only presented to the competition jury. As a disadvantage of this process, one could mention the great organizational difficulty associated with the exhibition and ensuring anonymity. Nevertheless, the process led to a succesful selection of the project that is already constructed.

Two examples of competitions with social participation have been found in Poland. In the autumn of 2017, the Capital City of Warsaw announced the 'Competition for the Development of Functional-Spatial Concept for a Central Square in Warsaw' - one of the main public spaces of Warsaw at the foot of the Palace of Culture and Science (Miasto Stołeczne Warszawa, 2017). A new formula was created in which five equivalent major prizes were awarded. After the announcement of the results of the competition, a public consultation was conducted. The result was used to select one competition entry for implementation. Thus, anonymity in the competition was maintained. In a legal sense the public consultations were shifted to the post competition procedure of 'negotiations without announcement'. Therefore, a sort of ploy has been used, which allows to bypass the requirements regarding anonymity contained in the Polish Public Procurement Act (2017). This solution has been criticised by many architects, who raised the point that the idea of the competition was violated as there was no $1^{\text {st }}$ prize awarded and in fact anonimity was not ensured.

Another competition that allowed social participation was the competition for the reconstruction of Aleja Marii Dąbrowskiej in Komorów, organized by the Poviat Pruszkowski and the Warsaw Branch of SARP (Oddział Warszawski SARP, 2017). In this case, a different formula was adopted. Social groups interested in the process appointed their representatives who were formally introduced to the competition process as external experts supporting the 
work of the competition jury. At the meeting of the jury, they gave a written opinion on individual projects submitted. The jury was obliged to take them into account. Thanks to this solution, the anonymity in the competition was preserved until the verdict was publicly announced.

\section{CONCLUSIONS}

As can be seen from the presented examples, there is no one recommended procedure that would ensure social participation. Probably more interesting examples could be found across Europe, but they all should meet common guidelines within the EU. The main difficulty is the need to maintain the legal framework that results from the long tradition of the competition, based on the anonymity of the participant. The social participation in the case hampers the preservation of this condition, hence various attempts to modify the existing formulas. It seems that there is a need to work out a clear regulation that would allow both values to be maintained. Perhaps separate study is needed to define which method is the most effective and should be recommended. It seems certain that the participation should be consultative for a jury's work, which consists of professionals and is able to balance contradictory arguments and make the final independent decision. Architectural competitions with social participation would allow then to obtain even better, properly selected design solutions. It seems that such a tool would be a high quality instrument positively influencing the building culture in Europe.

\section{REFERENCES}

1. Architects' Council of Europe. (2017). Public Participation in one or two phase Architectural Design Contest. Retrieved from: https://www.ace-cae.eu/policies/

2. Chupin, J-P., Cucuzzella, C., \& Helal, B. (2015). Architecture Competitions and the Production of Culture, Quality and Knowledge. Montreal: Potential Architecture books.

3. Miasto Stołeczne Warszawa. (2017). Competition for the Development of Functional-Spatial Concept for Central Square in Warsaw - comeptition rules and regulations. Retrieved from: http:// architektura.um.warszawa.pl/placcentralny.

4. Ministers of Culture assembled on the conference on 20-22 January 2018 in Davos, Switzerland. (2018). Davos declaration. Towards a high-quality Baukultur for Europe. Retrieved from: https://davosdeclaration2018.ch/programme/.

5. Sejm Rzeczypospolitej Polskiej. (2017). Ustawa Prawo Zamówień Publlicznych [Polish Public Procurement Act]. Retrieved from: http://prawo.sejm.gov.pl/isap.nsf/DocDetails. xsp?id=WDU20170001579.

6. Stadt Wolfsburg. (2013). Bildungshaus Wolfsburgoffener, zweiphasiger, hochbaulich-freiraumplanerischer Realisierungswettbewerb mit freiraumplanerischem Ideenteil - Auslobung. [Wolfsburg Education House two-phase competition - competition brief]. Retrieved from: https://www. luchterhandt.de/wp-content/uploads/2017/07/130819_169-auslobung_www.

7. Szambien, W. (1986). Les projets de l'an II, concours d'architecture de la période révolutionnaire. [Projects of the year II, architecture competitions of the revolution period]. Paris: Ecole nationale supérieure des Beaux-Arts.

8. The European Parliament and the Council of the European Union. (2014). Directive 2014/25/ EU of the European Parliament and of the council of 26 February 2014 on procurement by entities oper- 
ating in the water, energy, transport and postal services sectors and repealing Directive 2004/17/EC. Retrieved from: https:/ / eur-lex.europa.eu/legal-content/FRF/TXT/?uri=celex:32014L0025.

9. Oddział Warszawski SARP. (2001). Fragmenty stuletniej historii 1899-1999 ludzie fakty wydarzenia. [Fragments of a hundred year's history 1899-1999 people facts events]. Warszawa: Oddział Warszawski SARP.

10. Oddział Warszawski SARP. (2017). Konkurs na zagospodarowanie Alei Marii Dąbrowskiej w Komorowie [Competition for develpoment of Aleja Marii Dąbrowskiej in Komorów]. Retrieved from: http:// konkurs-alejamd.sarp.warszawa.pl/regulamin-konkursu/. 